\section{A Germination Study of Purple Sage}

\author{
Belinda Love', \\ Wayne S J ohnson ${ }^{2}$, and \\ George C.J. Fernandez ${ }^{3}$
}

Additional index words. Salvia dorrii (Kellogg) A brams, germination, propagation, natives, landscape shrub, temperature, gibberellic acid, stratification

\begin{abstract}
Summary. Germination of purple sage [Salvia dorrii (Kellogg) A brams] seed was evaluated under 21 temperature combinations (day temperatures from 5 to $30 \mathrm{C}$ and night temperatures from 5 to $30 \mathrm{C}$ ) in two experiments: 1) cool-moist stratification; and 2) sandpaper scarification, leaching with water, or gibberellic acid $\left(G A_{3}\right)$. T he quadratic responses of weighted germination percentage (WG P), a combined index of germination percentage and speed of germination, were significant $(P \leq 0.05)$ for all treatments. The interaction of day and night temperatures was significant ( $P \leq \mathbf{0 . 0 5})$ only for the 2-week stratification treatments and for the Expt. 2 control. Stratification increased WG $P$ over the control. 0 ptimal WG P for all stratification treatments ranged from $46 \%$ to $51 \% 0$ ptimal WG P was the same for both $\mathrm{GA}_{3}$ treatments. 0 ptimal WG $P$ for 0.29 mmol G $A_{3}$ occurred at $16 \mathrm{C}$ night temperature and $22 \mathrm{C}$ day temperature, and for the $1.44 \mathrm{mmol} \mathrm{GA}$ treatment at $18 \mathrm{C}$ night and at 30C day temperature.
\end{abstract}

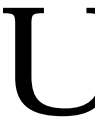

se of native and adapted exotic species is being emphasized to reduce landscape maintenance and to conserve water (J ohnson et al., 1990; Rodiek, 1984). Purplesageisanative evergreen shrub,

A gricultural Economics $\mathrm{D}$ epartment, $\mathrm{U}$ niversity of $\mathrm{Ne}$ vada, R eno, N V 89557.

${ }^{1} \mathrm{Graduate} s u d e n t$

${ }^{2}$ State H orticultural Extension Specialist.

${ }^{3} \mathrm{~A}$ ssistant Professor in Plant Breeding and Biometrics.

The cost of publishing thispaper was defrayed in part by the payment of page charges. U nder postal regulations, this paper therefore must be hereby marked advertisement solely to indicate thisfact.
2 to $5 \mathrm{dm}$ tall, with opposite, silver, round-obovate to spatulate leaves. It grows on arid, sandy, rocky, and disturbed sites throughout the Great Basin of the U nited States at elevations ranging from 762 to $3000 \mathrm{~m}$ (C ronquist et al., 1984; M unz, 1968; Starr, 1985). Therange of purplesageincludesWashington, Oregon, California, N evada, I daho, U tah, and Arizona. O nce established, purplesagerequireslittlesupplemental water or maintenance. D espite its ornamental potential, purple sage seldom is used because it is neither propagated nor grown in nurseries.

Little research hasbeen conducted on purple sage germination requirements. After 4 years of storage at 4C, purple sage seed germination percentage was greatest at $15 \mathrm{C}$, and roomtemperature storage decreased germination after 1 year of storage (Kay et al., 1988). We conducted germination studies using purple sage to determine the effects of constant and alternating temperatures and selected seed treatments on cumulative germination percentage (CGP), and weighted germination percentage (WGP), which is a combined index of germination percentage and speed of germination (Reddy et al., 1985).

Seeds were collected daily during July 1988 from field-grown shrubs established from seeds collected in the wild. Purple sage seeds ripened basipetally over several weeks in midsummer. Seed collection was timed to avoid loss of fully mature seed to shattering and to eliminate collecting large quantities of immature seeds, which decreases the viability percentage and increases seedcleaning difficulties. Four replications of 25 seeds each were placed on germination blotters in covered petri dishes in the dark, at 21 temperature combinations, which consisted of six constant and 15 alternating temperatures(T able $1)$.

Experiment 1. Becauselittlegermination research had been conducted on purplesage, and dormancy requirementswere unknown, westratified the seeds beginning $3 \mathrm{M}$ ay 1989 . T reatments included stratification on moistened blotter paper in petri dishesat $5 \mathrm{C}$ for $1,2,4$, and 8 weeks. Seeds were treated before placement in the 21 temperature combinations. After considering the stratification results, we choseto continuewith additional treatments based on the work of $\mathrm{N}$ ord et al. (1971) in a second experiment.

Experiment 2. These treatments included sandpaper-scarification (320A grade), leaching with deionized, distilled water ( $12 \mathrm{~h})$, and gibberellic acid $\left(\mathrm{GA}_{3}\right)$ soaks at $0.29 \mathrm{mmol}$ for $1 \mathrm{~h}$ or $1.44 \mathrm{mmol}$ for $30 \mathrm{~min}$. Seeds were treated before placement in the 21 temperature combinations on $30 \mathrm{Aug}$. 1989. E ach treatment was represented by four replications of 25 seeds in each of 21 temperaturecombinations. E vans et al. (1982) showed that 25 seeds per replication were sufficient when limited seedswereavailable. All trialslasted for 28 days and were checked daily for moisture and germination. Germination was considered complete when the radicle length reached $2 \mathrm{~mm}$.

Cumulativegermination percentage and weighted germination percentage (Reddy et al., 1985) were calculated. An arcsin transformation was performed on the germination percentages (Steel and Torrie, 1980), and a two-factor quadratic response surface regression analysis was performed on the germination data using the PCSAS-RSREG Procedure. An analysis of variance (AN OVA) al so was used to discriminateamong treatments at optimal day and night temperatures.

$D$ ay temperature significantly $(P$ $\leq 0.05)$ affected WGP, except for the $1.44 \mathrm{mmol} \mathrm{GA}$ for $30 \mathrm{~min}$, and the scarification treatments in Expt. 2. $\mathrm{N}$ ight temperatures also significantly affected WGP regardless of treatment in both experiments. Thelinear effects of day and night temperatures were

Table 1. D ay and night temperature combinations used in purple sage

\begin{tabular}{lllcccc}
\hline $\begin{array}{c}\text { Night }(16 \text { h) } \\
\text { temp }\left({ }^{\circ} \mathrm{C}\right)\end{array}$ & $\mathbf{5}$ & $\mathbf{1 0}$ & $\mathbf{1 5}$ & $\mathbf{2 0}$ & $\mathbf{2 5}$ & $\mathbf{3 0}$ \\
\cline { 2 - 7 } & $\mathrm{X}$ & $\mathrm{X}$ & $\mathrm{X}$ & $\mathrm{X}$ & $\mathrm{X}$ & $\mathrm{X}$ \\
5 & & $\mathrm{X}$ & $\mathrm{X}$ & $\mathrm{X}$ & $\mathrm{X}$ & $\mathrm{X}$ \\
10 & & & $\mathrm{X}$ & $\mathrm{X}$ & $\mathrm{X}$ & $\mathrm{X}$ \\
15 & & & & $\mathrm{X}$ & $\mathrm{X}$ & $\mathrm{X}$ \\
20 & & & & & $\mathrm{X}$ & $\mathrm{X}$ \\
25 & & & & & & $\mathrm{X}$ \\
30 & & & & & &
\end{tabular}


significant $(P \leq 0.05)$ for all treatments except the 4-week stratification treatment. The quadratic effects of day and night temperatures were significant ( $P$ $\leq 0.05$ ) for all treatments, whereas the cross-products were significant ( $P \leq$ 0.05) only for the control of the $\mathrm{GA}_{3}$ and the 2-week stratification treatments in Expt. 1. The significant linear and quadratic effects imply that the WGP increased with the increase in day and night temperaturesup to the optimum day and night temperature combination. Beyond the optimum day-night temperature combinations, the WGP decreased with the increase in both temperatures. The prediction of WG P by the response-surface model for the scarification treatment (Expt. 2) was not as successful $\left(R^{2}<0.30\right)$ as the other treatments.

\section{Experiment 1}

Strati fication treatments. 0 ur

\section{a. Control}

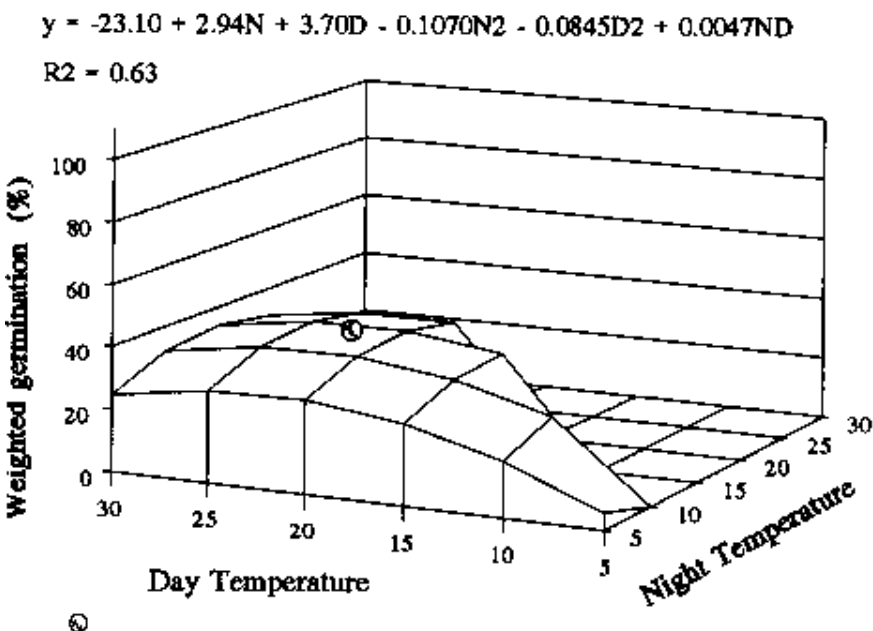

\section{b. Stratification - 1 week}

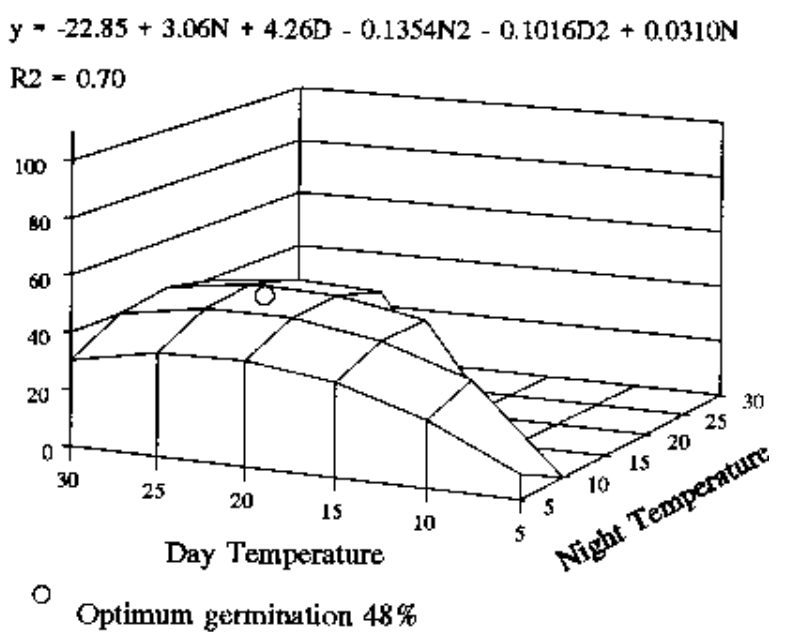

\section{c. Stratification - 2 week}

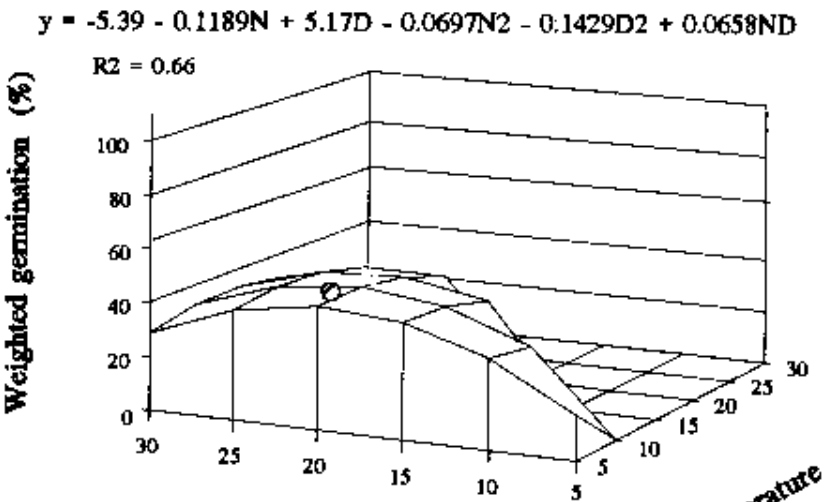

0

Day Temperature

Optimum germination $46 \%$

\section{d. Stratification - 4 week}

$y=-1003+2.67 \mathrm{~N}+4.210-0.0560 \mathrm{~N} 2-0.0936 \mathrm{D} 2-0.0466 \mathrm{ND}$

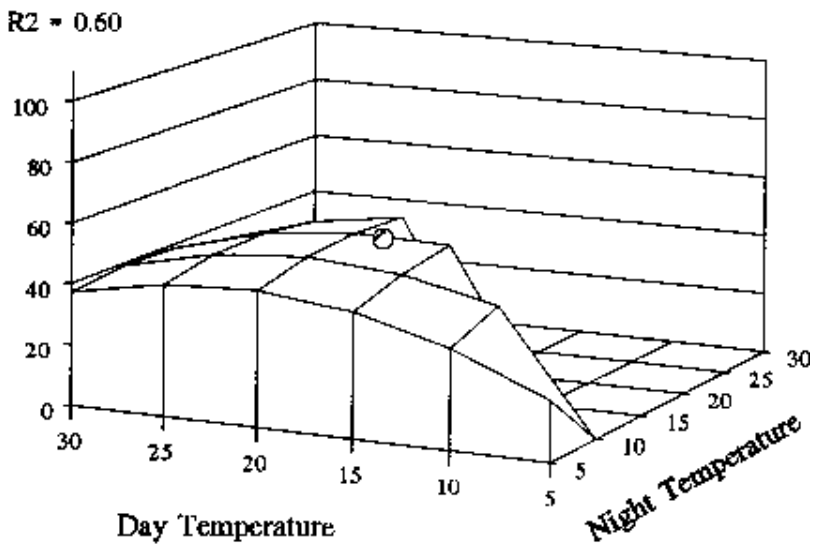

${ }^{O}$ Oplimum getmination $51 \%$

Fig. 1. Stratificati on and day and night temperature effects on weighted germi nati on percentages of purple sage sed. 


\section{RESEARCH UPDATE}

work indicated that 8 weeks of stratification resulted in the greatest overall WGP, but seed began to germinate during the 7th week of the 8-week stratification period, prior to placement in alternating temperatures (data not presented). Thus, 6 weeks of cold stratification at $5 \mathrm{C}$ may be sufficient to enhance germination. Stratification

\section{a. Control}

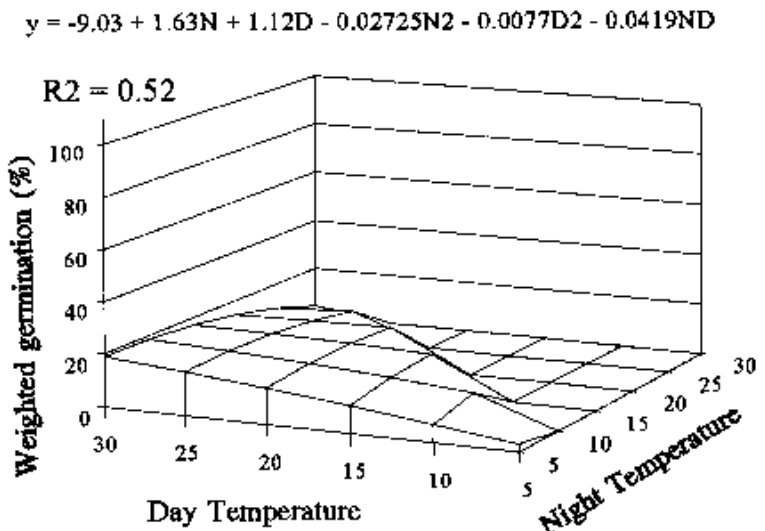

\section{c. GA3 $0.29 \mathrm{mmol} 1 \mathrm{hr}$}

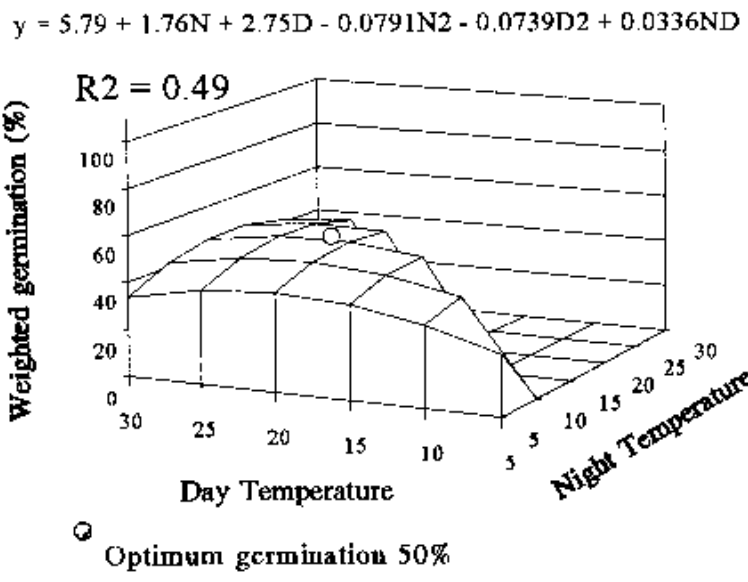

\section{b. Leaching - $1 \mathrm{hr}$}
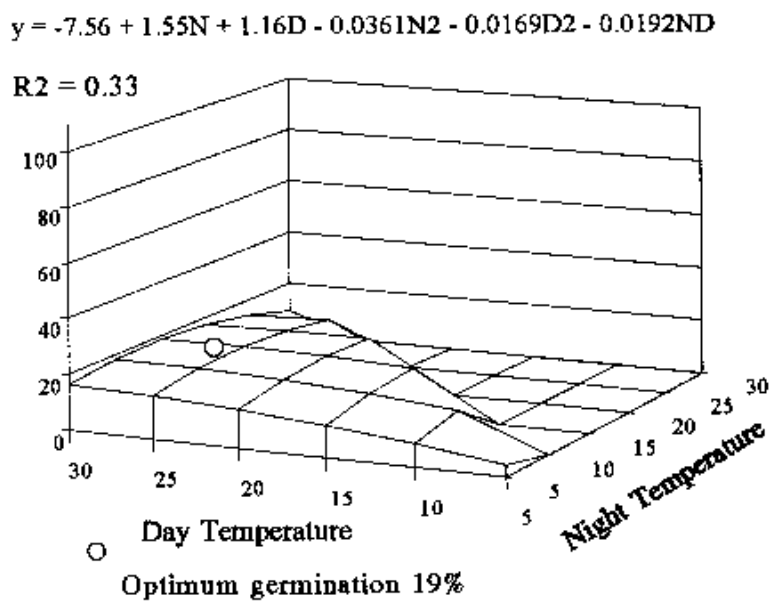

\section{d. GA3 $1.44 \mathrm{mmol} 30 \mathrm{~min}$}

$y=14.46+2.49 \mathrm{~N}+0.8601 \mathrm{D}-0.0765 \mathrm{~N} 2-0.0171 \mathrm{D} 2+0.0099 \mathrm{ND}$

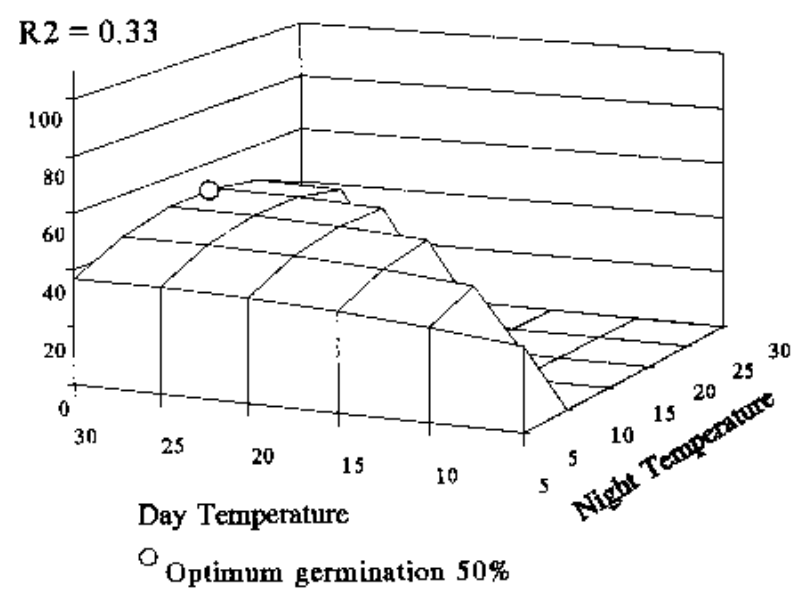

e. Scarification

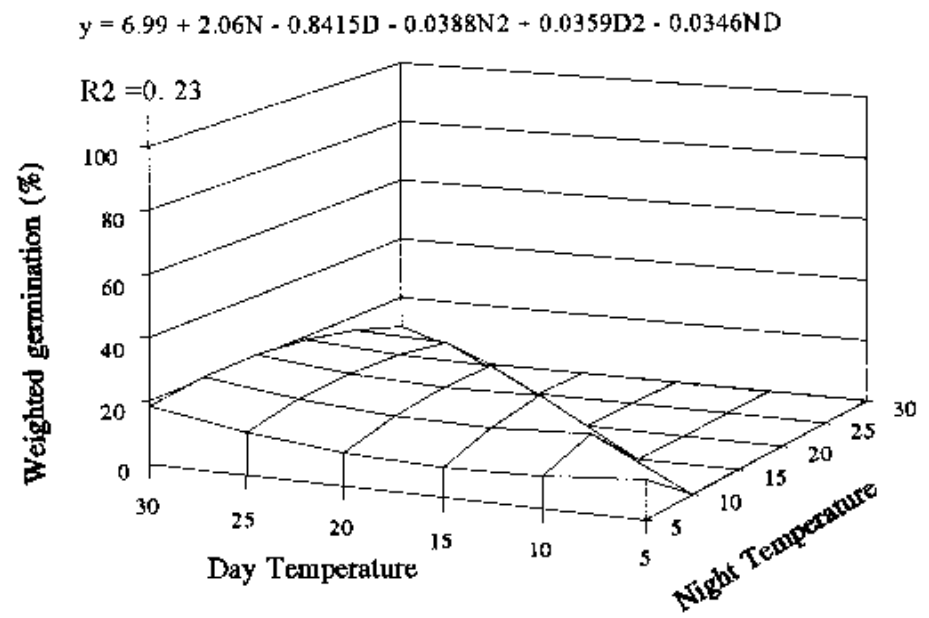

Fig. 2. GA $\mathrm{A}_{3}$ and day and night temperature effects on weighted germi nati on percentages of purple sage sed. 
increased WG P over that of the control (Fig. 1 a-d). Optimal WGP for all stratification treatments ranged from $46 \%$ to $51 \%$ Although optimal WGP occurred at similar temperature combinations for the control (Fig. 1a) and after 1 week of stratification (Fig. Ib), it occurred at lower day and night temperatures after 2 weeks of stratification (Fig. 1c). Stratification for 4 weeks (Fig. 1d) resulted in increased WGPS over the range of night temperatures.

\section{Experiment 2}

Gibber ellic acid treatments. Both $\mathrm{GA}_{3}$ treatments $(0.29 \mathrm{mmol}$ for $1 \mathrm{~h}$ and $1.44 \mathrm{mmol}$ for $30 \mathrm{~min}$ ) stimulated germination over a wide range of temperatures (Fig. 2 c-d). O ptimal WGP was the same for the two treatments, but optimal temperature combinations were not. O ptimal WGP for 0.29 mmol GA $A_{3}$ occurred at $16 \mathrm{C}$ night temperature and at $22 \mathrm{C}$ day temperature, and for the $1.44 \mathrm{mmol} \mathrm{GA}$ treatment at $18 \mathrm{C}$ night and at $30 \mathrm{C}$ day temperature.

$\mathrm{N}$ either leaching (Fig. 2b) nor scarification (Fig. 2e) enhanced germination. The lack of a response indicates a lack of water-soluble inhibitors in the seed coat or in the seed; thus, seed coat permeability may not limit germination. The control, scarification, and leaching (Fig. 2a) showed a marked decrease in germination compared with the control for stratification (Fig. 1a) (stratification treatments were executed 3 months before the other set of treatments). Thus, germination of untreated seed may decrease after storage, supporting the observations by Kay et al. (1988).

Theoptimal temperatures differed with treatment. For all stratification and $\mathrm{GA}_{3}$ treatments, optimal day temperature ranged from 18 to $30 \mathrm{C}$, and optimal night temperatureranged from 9 to $18 \mathrm{C}$. When seeds were treated with $\mathrm{GA}_{3}$, germination was relatively uniform over all temperature combinations. When night temperature ranged from 16 and $18 \mathrm{C}$, stratification
Table 2. Cumulati ve germinati on percentage and weighted germinati on treatment meansafter 28 daysat $15 \mathrm{C}$ night ( $16 \mathrm{~h}$ ) and $25 \mathrm{C}$ day $(8 \mathrm{~h})$ temperatures

\begin{tabular}{|c|c|c|}
\hline T reatment & $\begin{array}{c}\text { Cumulative } \\
\text { germination (\%) }\end{array}$ & $\begin{array}{c}\text { Weighted } \\
\text { germination (\%) }\end{array}$ \\
\hline \multicolumn{3}{|c|}{ Experiment 1} \\
\hline Control & $50.5 A B^{2}$ & $40.9 \mathrm{BC}$ \\
\hline $\begin{array}{l}\text { Stratification, } \\
1 \text { week }\end{array}$ & $55.7 \mathrm{~A}$ & $49.5 \mathrm{~A}$ \\
\hline $\begin{array}{l}\text { Stratification, } \\
2 \text { weeks }\end{array}$ & $42.7 \mathrm{~B}$ & $38.8 \mathrm{C}$ \\
\hline $\begin{array}{l}\text { Stratification, } \\
4 \text { weeks }\end{array}$ & $54.5 \mathrm{~A}$ & $50.3 \mathrm{~A}$ \\
\hline & Experiment 2 & \\
\hline $\begin{array}{l}\text { Control } \\
\mathrm{GA}_{3}, 0.29\end{array}$ & $25.5 \mathrm{~B}$ & $17.2 \mathrm{C}$ \\
\hline $\begin{array}{l}\mathrm{mmol}, 1 \mathrm{~h} \\
\mathrm{GA}_{3}, 1.44\end{array}$ & $52.1 \mathrm{~A}$ & $47.5 \mathrm{~A}$ \\
\hline $\mathrm{mmol} 30 \mathrm{~min}$ & in $55.7 \mathrm{~A}$ & $50.6 \mathrm{~A}$ \\
\hline L each & $27.6 \mathrm{~B}$ & $23.9 \mathrm{~B}$ \\
\hline Scarification & $22.7 \mathrm{~B}$ & $16.6 \mathrm{C}$ \\
\hline
\end{tabular}

${ }^{\mathrm{z} M}$ eans within experiments followed by the same letter arenot significantly different according to Waller-D uncan'st-test with K -ratio $=100$.

for 2 and 4 weeks and $0.29 \mathrm{mmol} \mathrm{GA}_{3}$ for $1 \mathrm{~h}$ had optimal germination percentages between 18 and $22 \mathrm{C}$ day temperature, while1.44 $\mathrm{mmol} \mathrm{GA}_{3}$ for 30 min had an optimal germination percentage at $30 \mathrm{C}$. Thus, $1.44 \mathrm{mmol}$ $\mathrm{GA}_{3}$ for 30 min germinated at high day temperatures.

AN OVA were performed to discriminate among treatment means in both experiments at $15 \mathrm{C}$ night temperature and $25 \mathrm{C}$ day temperature. These temperatures fell within optimal temperature ranges and more closely represented spring germination conditions. The WGPS for the stratification for 1 and 4 weeks were significantly higher than the control and stratification for 2 weeks in Expt. 1 (Table 2). Why germination decreased after 2 weeks of stratification was not determined by this experiment, but these results deserve further study. I n Expt. 2, WG P for $1.44 \mathrm{mmol}$ $\mathrm{GA}_{3}$ for $30 \mathrm{~min}$ and $0.29 \mathrm{mmol} \mathrm{GA}$ for $1 \mathrm{~h}$ were significantly higher com- pared to the remaining treatments (Table 2).

Stratifying purple sage seed for 1 or 4 weeks or treating them with 0.29 $\mathrm{mmol} \mathrm{GA}_{3}$ for $1 \mathrm{~h}$ at an optimum day temperature between 18 and $30 \mathrm{C}$ and a night temperature ranging between 9 to $18 \mathrm{C}$ are recommended for optimum germination. The rate of germination with $\mathrm{GA}_{3}$ treatment was more rapid and produced equally successful results; therefore, we recommend it when $\mathrm{GA}_{3}$ is available.

\section{Literature Cited}

Cronquist, A, A.H. H olmgren, N.H. H olmgren, J.L. R eveal, and P.K. H olmgren. 1984. Vascular plants of theintermountain west. vol. 4. N ew York Botanical Garden.

Evans, R.A., D.A. Easi, D.N. Book, and J .A. Y oung. 1982. Q uadratic response surface analysis of seed-germination trials. Weed Sci. 30:411-416.

J ohnson, C.W., F.A. Baker, and W.SJ ohnson. 1990. U rban and community forestry: A guide for the cities and towns of the interior U nited States. Forest Service, U SD A, Intermountain Region, O gden, U tah.

Kay, B.L., W.L. Graves and J.A. Young. 1988. L ong-term storage of desert shrub seed. M ojave R evegetation $N$ otes 23.

M unz, P.A. 1968. A Californiaflora. U niv. of California Press, Berkeley.

N ord, E.C., L. E. Gunter, and S.A. Graham, Jr. 1971. Gibberellic acid breaks dormancy and hastens germination of creeping sage. Forest Service, U SD A, Res. N ote PSW-259.

R eddy, L.V., R .J . M etzger, and T.M . C hing. 1985. E ffects of temperatures on seed dormancy of wheat. Crop Sci. 25:455-458.

R odiek, J. 1984. Water conservation strategies for the urban arid landscape. D esert Plants 6(1).

Starr, G. 1985. N ew World salvias for cultivation in southern A rizona. D esert Plants 7(4):167-207

Sted, R.G.D . and J.H. Torrie. 1980. Principles and procedures of statistics. 2nd ed. $\mathrm{M}$ cG raw-H ill, N ew York. 